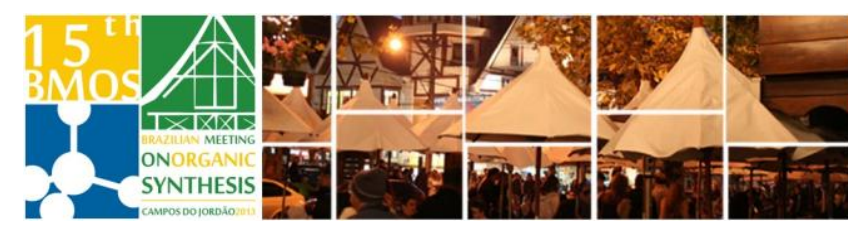

\title{
Synthesis of Thiophene Acetylenes via Sonogashira Cross- Coupling Reactions
}

\author{
Diego B. Carvalho ${ }^{1}$; Camila B. Andrade ${ }^{1}$; Carla R. Z. Miranda1, Gabriela R. Hurtado ${ }^{1}$, \\ Luiz H. Viana'; Palimécio G. Guerrero Jr. ${ }^{2}$ and Adriano C. M. Baroni ${ }^{1^{*}}$ \\ ${ }^{1}$ LASQUIM - Laboratório de Síntese e Química Medicinal, Universidade Federal do Mato Grosso do Sul, \\ UFMS, Campo Grande/MS, 79070-900, Brazil. \\ ${ }^{2}$ Departamento de Química e Biologia, DAQBi, Universidade Tecnológica Federal do Paraná, UTFPR, \\ Curitiba/PR, 80230-901, Brazil. \\ *adriano.baroni@ufms.br
}

Keywords: Sonogashira cross-coupling reactions; 3-iodothiophenes; thiophene acetylenes, TBAOH.

\section{INTRODUCTION}

Organochalcogene compounds ( $\mathrm{S}$, Se and Te) have been investigated in recent decades because of their many applications in synthetic organic chemistry, preparation of new materials, and medicinal chemistry. Among them, the thiophene group has emerged in recent years as one of the most-studied compounds by synthetic organic chemists, due to being found in various chemical compounds, with a broad range of applications in the electronics industry to produce electroluminescent diodes (OLED), organic field effect transistors (OFET), photovoltaic cells, sensors, semiconductors, liquid crystals and "displays". ${ }^{1}$ Because of the strong interest in the synthesis of new thiophene compounds and its applications, in this communication we show our results in the synthesis of thiophene acetylenes through Sonogashira cross coupling reactions.

\section{RESULTS AND DISCUSSION}

For the synthesis of the thiophene acetylenes type 2, Sonogashira cross-coupling reactions were performed using 3-iodothiophene 1 (1 $\mathrm{mmol})$ and heptyne (2mmol) in THF (3ml), $\mathrm{PdCl}_{2}\left(\mathrm{PPh}_{3}\right)_{2} 5 \%$ and Cul $10 \%$ as catalytic system and 2 equiv. of $\mathrm{Et}_{3} \mathrm{~N}$. In this case, thiophene acetylene $2 \mathrm{a}$ was obtained in $62 \%$ yield after $48 \mathrm{~h}$ of reaction at room temperature (Scheme 1, Table 1).

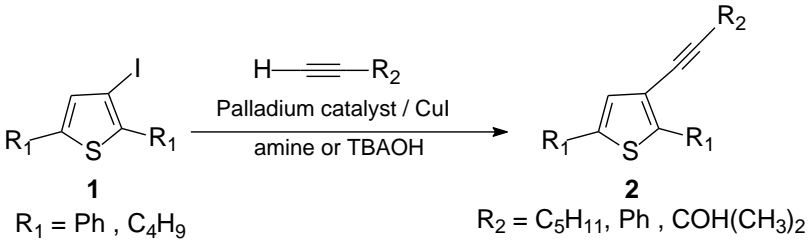

Considering of the elevated time reaction we made a systematic study, changing palladium catalysts, amines, and use of $\mathrm{TBAOH} 40 \%$ in water as phase transfer catalyst (PTC). ${ }^{2}$

In Table 1 we show the results in different reactions conditions. The use of $\mathrm{TBAOH}$ in substitution to the $\mathrm{Et}_{3} \mathrm{~N}$ or pyrrolidine, showed the best results (Scheme 1, Table 1).

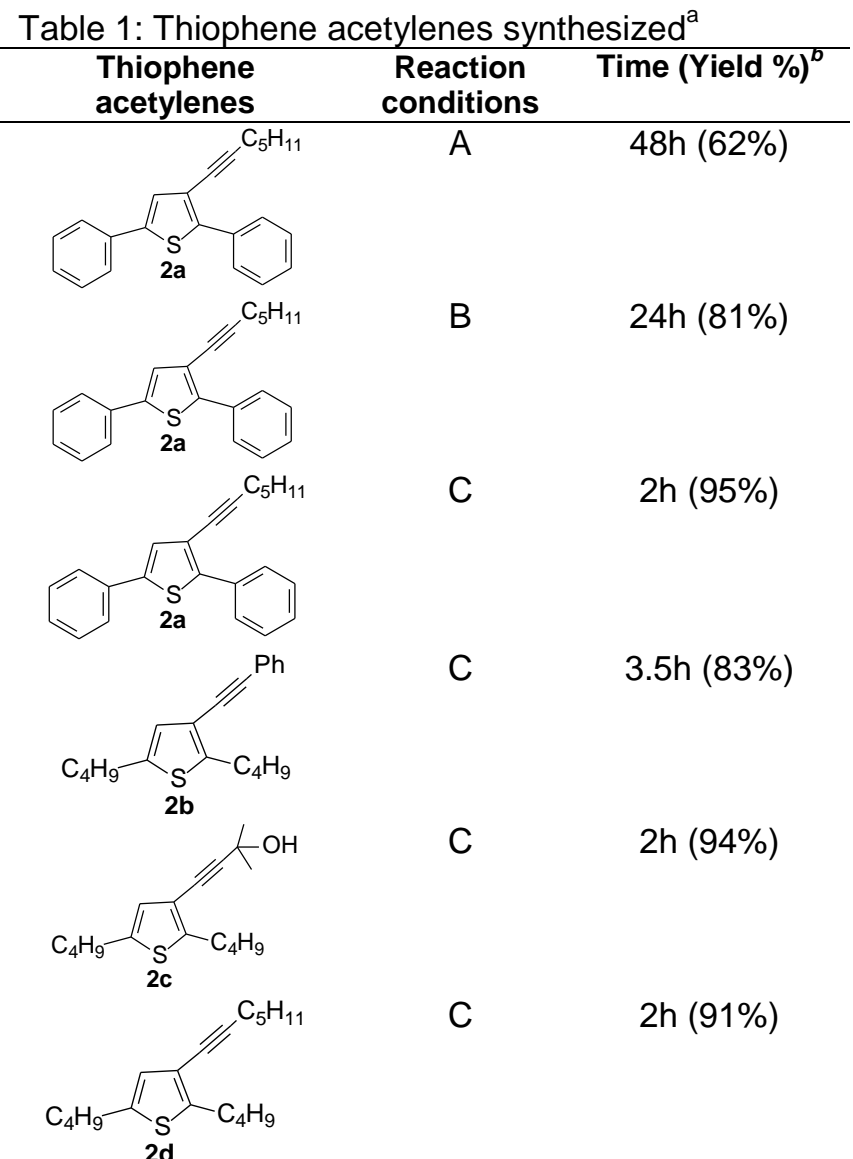

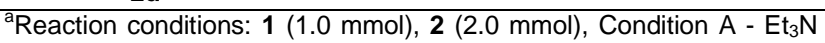
$(2.0 \mathrm{mmol})$ at rt in THF, catalytic system: $\mathrm{PdCl}_{2}\left(\mathrm{PPh}_{3}\right)_{2} 5 \% / \mathrm{Cul} 10 \%$, Condition B - Pyrrolidine $(2.0 \mathrm{mmol})$ at it in THF, catalytic system: $\mathrm{Pd}\left(\mathrm{PPh}_{3}\right)_{4} 5 \%$ / Cul 10\%, Condition C - TBAOH (2.0 mmol), $\mathrm{Pd}\left(\mathrm{PPh}_{3}\right)_{4}$ $5 \% / \mathrm{Cul} 10 \%$ and THF $(3.0 \mathrm{ml}) / \mathrm{MeOH}(3 \mathrm{ml})$ at rt. ${ }^{\mathrm{b}}$ isolated products.

\section{CONCLUSION}

The results obtained in the synthesis of thiophene acetylenes using $\mathrm{Pd}\left(\mathrm{PPh}_{3}\right)_{4} / \mathrm{Cul}$ and $\mathrm{TBAOH}$ as PTC in substitution of amines were very satisfactory.

\section{ACKNOWLEDGEMENTS}

FUNDECT-MS, CAPES, CNPq, PROPP-UFMS.

\section{REFERENCES}

${ }^{1}$ Kaniskan, N.; Elmali, D.; Civcir, P. U. Arkivoc 2008, 12, 17.

Baroni, A. C. M. et all Tetrahedron Lett. 2011, 52, 4177 